\title{
PENYELESAIAN KONFLIK ANTARA PEMERINTAH DAERAH NUSA TENGGARA BARAT DENGAN PT. ECO SOLUTIONS LOMBOK: KASUS SENGKETA PENGELOLAAN HUTAN LINDUNG SEKAROH
}

\author{
CONFLICT RESOLUTION BETWEEN THE LOCAL \\ GOVERNMENT OF WEST NUSA TENGGARA AND PT. \\ ECO SOLUTIONS LOMBOK: A CASE OF SEKAROH FOREST \\ MANAGEMENT
}

\author{
Mala Mardialina \\ Universitas Mataram \\ email : mala.mardialina@unram.ac.id
}

\author{
Ahmad Mubarak M. \\ Universitas Mataram \\ email : mubarakmunir44@gmail.com
}

\begin{abstract}
Forest area management is a major challenge in enforcing forest functions in accordance with statutory regulations. Investment in forest area management as a tourist attraction is often a problem. This paper aims to explain various efforts in conflict resolution between the Local Government and PT. Eco Solutions Lombok by analyzing the roots of the conflict and mapping the conflicts. This research is empirical research with a qualitative research method. Data obtained from interviews, books, journals, reports, and online sites. The summary of the research results is the enactment of Law 32 has resulted in a significant reduction in conflict escalation between the Local Government and PT. Eco Solutions Lombok, It's proven by withdrawing the lawsuit in court and giving changes to the attitudes of each actor, the actor's transformation runs quickly and the conflict breaks down into positive peace.
\end{abstract}

Keywords: Conflict Resolution; Forest Management; Conflict Transformation

\begin{abstract}
Abstrak
Tata kelola kawasan hutan menjadi tantangan utama dalam menegakkan fungsi hutan sesuai dengan aturan undang-undang. Investasi dalam bidang pengelolaan kawasan hutan sebagai objek wisata tidak jarang menjadi sebuah masalah. Tulisan ini bertujuan untuk menjelaskan berbagai upaya dalam penyelesaian konflik antara Pemerintah Daerah dan PT. Eco Solutions Lombok dengan menganalisis akar konflik dan memetakan konflik yang terjadi. Penelitian ini adalah penelitian empiris dengan metode penelitian kualitatif. Data diperoleh dari wawancara, buku, jurnal, laporan dan situs online. Ringkasan hasil penelitian adalah pemberlakuan Undang-undang 32 telah berdampak pada menurunnya eskalasi konflik secara signifikan antara Pemerintah Daerah dan PT. Eco Solutions Lombok dibuktikan dengan pencabutan gugatan di pengadilan dan memberikan perubahan pada sikap setiap aktor, transformasi aktor berjalan cepat sehingga konflik terurai ke arah positive peace.
\end{abstract}

Kata Kunci: Resolusi Konflik; Pengelolaan Kawasan Hutan; Transformasi Konflik 


\section{PENDAHULUAN}

Indonesia merupakan negara tropis dengan luas kawasan hutan mencapai 124 juta hektare, dikenal sebagai megadiverse country karena memiliki hutan terluas dan tingkat keanekaragaman hayati terkaya di dunia. Luasnya kawasan hutan Indonesia mengalami degradasi setiap tahunnya, menurut data yang dirilis oleh Badan Pangan dan Pertanian Dunia atau Food Agriculture Organization (FAO) Indonesia menjadi negara peringkat kedua tertinggi kehilangan kawasan hutan setelah Brazil. Akibat illegal logging, kebakaran hutan, alih fungsi hutan dan perambahan, Indonesia kehilangan 684.000 hektare hutan setiap tahunnya. ${ }^{1}$

Layaknya sektor perikanan dan pertambangan, hutan juga menjadi magnet tersendiri dalam kegiatan ekonomi, baik yang dilakukan secara legal maupun ilegal. Setidaknya terdapat 883 juta orang menggantungkan prekonomiannya di sektor kehutanan, artinya bahwa hutan memiliki fungsi lain sebagai skema mendorong kesejahteraan masyarakat. Selain sebagai pendorong kesejahteraan masyarakat, sektor kehutanan juga menjadi penyumbang pemasukan negara dan sekaligus sebagai menentukan perkembangan ekonomi global. Sektor kehutanan Indonesia pada tahun 2015 mampu memberikan Pendapatan Negara Bukan Pajak (PNBP) sebesar 5,5 triliun, melampaui target 4 triliun. ${ }^{2}$

Dimensi sosial politik sektor kehutanan secara signifikan memberikan dampak yang sangat besar dalam mendorong kesejahteraan masyarakat Indonesia, baik yang bersumber dari hasil kehutanan dan pemanfaatan kawasan hutan sebagai sektor industri, sebagai contoh industri pariwisata. Meningkatnya pemanfaatan hutan sebagai sektor industri, memicu terjadinya konflik dalam konteks perijinan dan timpang tindih aturan serta pemanfaatan kawasan hutan secara ilegal oleh masyarakat. Kompleksnya permasalahan yang ditimbulkan dari proses pemanfaatan kawasan hutan ini juga didorong oleh konsistensi pemangku kebijakan dalam hal ini pemerintah daerah sebagai otoritas pemegang izin kelola kawasan hutan.

Konflik terkait dengan pengelolaan hutan antara pemerintah, masyarakat dan perusahaan banyak terjadi di Indonesia. Permasalahan pengelolaan hutan yang berujung konflik misalnya terjadi di Provinsi Lampung, sebanyak $42 \%$ dari kasus konflik agraria terjadi di lahan hutan negara dan tanah marga-- dalam rentang waktu 1960-2000 tercatat setidaknya telah terjadi alih fungsi lahan dengan berbagai skema. Misalnya dengan skema pemanfaatan lahan bagi swasta melalui Hak Guna Lahan, Hak Pengusahaan Lahan, Hak Guna Bangunan dan berbagai skema lain misalnya Hak Ulayat, Hak Marga dan Hak Kekerabatan. Konflik Sumberjaya di Lampung Barat misalnya, bupati pertama

\footnotetext{
${ }^{1}$ Hendra Cipto, Setiap Tahun, Hutan Indonesia Hilang 684.000 Hektar, https://regional.kompas.com/komentar/2016/08/30/15362721/setiap.tahun.hutan.indonesia.hilang.684.000.hektar, diakses tanggal 6 Maret 2017.

${ }^{2}$ Pidato Menteri Lingkungan Hidup dan Kehutanan Pada Apel Rimbawan Peringatan Hari Bhakti Rimbawan Tahun 2017, Kamis 16 Maret 2017.
} 
di Indonesia yang kemudian memberikan izin pemanfaatan hutan melalui skema Hutan Kemasyarakatan (HKm) dengan SK Menteri No. 31/Kpts-II/2001 mengenai pemberian izin yang sifatnya partisipatif. ${ }^{3}$

Kompleksitas pengelolaan hutan didorong juga oleh kebijakan yang tidak tepat dan kerapkali berubah; contohnya kebijakan otonomi daerah pasca reformasi 1998. Penyimpangan dari proses desentralisasi dalam pengelolaan hutan adalah timbulnya kebebasan yang tidak terkendali dari pemerintah-pemerintah daerah termasuk dalam pemanfaatan sumberdaya alam berupa hutan yang ada di dalam wilayah administratif mereka. Kebebasan penggunaan hutan memberikan dampak yang buruk terhadap sumberdaya air, produktivitas pertanian, dan membawa ancaman terhadap lingkungan hidup yang tidak terbatas pada wilayah administratif di mana hutan tersebut berada. ${ }^{4}$ Tafsir daerah atas aturan mengenai kehutanan mengakibatkan banyak konsekuensi, misalnya pengeluaran izin untuk menggunakan hutan bagi pihak swasta, hal ini dikemudian hari menjadi konflik antara swasta dan pemda mengingat politik di daerah sangat dinamis.

Dalam membangun sebuah kerangka kerjasama antara pemerintah dan masyarakat terkait dengan pengelolaan hutan dilakukan dengan mendorong partisipasi dan pemberdayaan. Perhutanan sosial (social forestry) menjadi skema pemberdayaan yang ditawarkan pemerintah dengan melibatkan masyarakat dalam skema pengelolaan dan pemanfaatan hutan. Langkah ini diharapkan menjadi pengurai konflik dalam pengelolaan hutan, meskipun kesalahan pemberian wewenang dalam pengelolaan menjadi pemicu konflik di kemudian hari. Beberapa faktor yang medorong pemberdayaan belum efektif antara lain; pemberdayaan dilakukan sangat prosedural, tidak menyentuh masyarakat secara holistik; kebijakan program masih bersifat sentralistik dan penetapan area, aturan serta pelibatan mitra yang kurang tepat. ${ }^{5}$

Social forestry dapat diartikan sebagai pendekatan yang dilakukan untuk mitigasi peningkatan deforestasi dan degradasi hutan serta mengatasi dampak negatif dari aktivitas masyarakat lokal di hutan dengan melibatkan masyarakat sebagai subjek dalam melakukan pengelolaan hutan. ${ }^{6}$ Program ini menjadi langkah strategis pemerintah dalam pengelolaan hutan yang di kemudian hari menjadi salah satu pemicu konflikkonflik dalam proses pengelolaan hutan. Dinamika politik di daerah menjadi salah satu faktor yang mendorong terjadinya distorsi semangat pengelolaan hutan yang berkelanjutan. Pelibatan masyarakat dalam pengelolaan hutan tidak sepenuhnya selalu

\footnotetext{
${ }^{3}$ Bruno Verbist \& Gamal Pasya, Perspektif Sejarah Status Kawasan Hutan, Konflik dan Negosiasi di Sumberjaya, Lampung Barat-Propinsi Lampung, Agrivita Vol. 26 No. 1 Edisi Maret 2004, hlm. 23-27.

${ }^{4}$ Baharuddin Nurkin, Otonomi Daerah dan Pengelolaan Sumberdaya Alam: Kasus Pengelolaan Hutan di Sulawesi Selatan, Perennial: Pengelolaan Hutan dan Pemanfaatan Hasil Hutan, Vol. 2 No. 1 Edisi Januari 2006, hlm. 27.

${ }^{5}$ Slamet Edi Sumanto, Kebijakan Pengembangan Perhutanan Sosial Dalam Perspektif Resolusi Konflik, Jurnal Analisis Kebijakan Kehutanan, Vol. 6 No. 1 Edisi April 2009, hlm. 16-18.

${ }^{6} \mathrm{Ni}$ Putu Sekar T Laksemi, Endah Sulistyawati, Mulyaningrum, Perhutanan Sosial Berkelanjutan di Provinsi Bali (Studi Kasus di Hutan Desa Wanagiri), Jurnal Sylva Lestari, Vol. 7 No. 2 Edisi Mei 2019, hlm. 152.
} 
menimbulkan konflik baru, salah satu contoh dalam pengelolaan Hutan Leksono di Kabupaten Wonosobo. Melalui skema pengelolaan hutan bersama masyarakat (PHBM) secara efektif mampu memberikan manfaat luas dengan potensi konflik yang rendah. Kemampuan dalam memetakan stakeholder dan memberikan peranan yang seimbang mampu menjadi penjaga dinamika dalam proses pengelolaan hutan di masa depan. ${ }^{7}$

Konflik pemanfaatan hutan lindung Sekaroh di Kecamatan Jerowaru, Kabupaten Lombok Timur menjadi salah satu konflik dalam sektor kehutanan yang cukup kompleks. Kawasan hutan Sekaroh setidaknya mencakup beberapa objek wisata yang cukup fenomenal seperti Pantai Pink, Bukit Tanjung Ringgit dan pantai lainnya. Kompleksitas konflik di kawasan ini dapat dilihat dari beberapa permasalahan yang timbul seperti misalnya kepemilikan sertifikat tanah yang tidak berdasar, perambahan dan pengelolaan hutan secara ilegal, alih fungsi hutan sebagai lahan pertanian jagung dan cabai.

Permasalahan tidak hanya terjadi antara masyarakat dan pemerintah daerah, namun konflik antara pemerintah daerah dan pihak pengembang objek wisata juga terjadi. Bupati Kabupaten Lombok Timur, H. Ali Bin Dahlan secara sepihak menganulir izin PT. Eco Solutions Lombok (ESL) yang sebelumnya mendapat izin kelola dari Kementerian Kehutanan dan Bupati Lombok Timur, H. Sukiman, periode 2009-2013. Izin kelola selanjutnya diberikan oleh bupati selanjutnya, yakni H. Ali Bin Dahlan kepada beberapa investor antara lain PT. Palamarta Persada, PT. Lombok Saka pada tanggal 4 April 2014, PT. Tanah Hufa tanggal 10 November 2014 dan PT. Ocean Blue pada tahun 2015. ${ }^{8}$

Konflik kepentingan yang terjadi di atas Hutan Lindung Sekaroh sarat akan penegakan hukum yang lemah, mengabaikan berbagai petunjuk pengelolaan hutan yang diatur undang-undang serta peraturan menteri. Penelitian ini akan mencoba menelusuri lebih dalam berbagai upaya dalam penyelesaian konflik antara pemerintah daerah dengan PT. Eco Solutions Lombok dengan menganalisis akar konflik serta memetakan konflik. Penelitian ini dibingkai dalam tema besar "Upaya Penyelesaian Konflik Pemerintah Daerah Lombok Timur dengan PT. Eco Solutions Lombok (ESL): Studi Kasus Pengelolaan Hutan Lindung Sekaroh". Adapun rumusan masalah dalam penelitian ini, yaitu 1) Bagaimana situasi permasalahan di kawasan Hutan Sekaroh?; 2) Bagaimana kronologis konflik pengelolaan kawasan Hutan Sekaroh?; dan 3) Bagaimana upaya penyelesaian konflik Pemerintah Daerah Lombok Timur dengan PT. Eco Solutions Lombok?

Penelitian ini bertujuan antara lain pertama, memahami penetapan kawasan Sekaroh sebagai hutan lindung, Kedua, untuk mengetahui kompleksitas masalah dalam

\footnotetext{
${ }^{7}$ M. Imam Arifandy, Martua Sihaloho, Efektivitas Pengelolaan Hutan Bersama Masyarakat Sebagai Resolusi Konflik Sumber Daya Hutan, Sodality:Jurnal Sosiologi Pedesaan, Vol. 3 No. 5 Edisi Maret 2016, hlm. 148-150.

${ }^{8}$ Dhimas Budi Pratama, Penyidik Kejaksaan Koordinasikan Kasus Hutan Sekaroh, https://mataram.antaranews. com/berita/38594/penyidik-kejaksaan-koordinasikan-kasus-hutan-sekaroh, diakses tanggal 6 Maret 2017.
} 
pengelolaan kawasan hutan Sekaroh, Ketiga, memahami kronologis konflik dalam izin pengelolaan hutan Sekaroh, Keempat, untuk menggali upaya penyelesaian konflik pengelolan kawasan hutan antara pemerintah daerah dan PT. Eco Solutions Lombok. Penelitian ini adalah penelitian kualitatif, proses pengumpulan data diperoleh melalui wawancara dengan aktor yang terlibat dalam konflik, dan melalui kajian literatur berupa buku, jurnal, laporan dan situs website. Kajian mengenai konflik Hutan Sekaroh pernah dibahas oleh Catur Bowo Susbiarto. Ia mencoba menggambarkan konflik antara Dinas Kehutanan dengan pemegang hak atas tanah Hutan Sekaroh yang merupakan kawasan hutan sesuai dengan keputusan Menteri Pertanian No. 756/Kpts/Um/10/1982. ${ }^{9}$ Dalam penelitiannya, Susbiarto mencoba menganalisis konflik pemerintah daerah dengan pemegang hak atas tanah Hutan Sekaroh, sedangkan penelitian ini fokus pada konflik antara pemerintah dengan perusahaan yang mendapat izin pengembangan kawasan tersebut dalam pengembangan pariwisata. PT. Eco Solutions Lombok menjadi pihak yang paling dirugikan atas berlarut-larutnya kasus pengelolaan hutan ini. Penelitian ini akan memberikan analisis dinamika konflik lahan di kawasan Hutan Sekaroh antara pemilik modal dengan pemerintah daerah yang juga memiliki kepentingan besar dibalik izin yang diterbitkan.

\section{PEMBAHASAN}

\section{Penetapan Kawasan Hutan Sekaroh}

Luas hutan lindung di Indonesia hingga tahun 2002 mencapai 20 juta hektar, kebijakan pengelolaan hutan lindung di Indonesia melibatkan pemerintah pusat dan daerah. Sedangkan luasan dan tata batas area hutan lindung ditetapkan dengan SK Menteri, perlu dipahami bahwa reformasi tahun 1998 memberikan dampak serius bagi payung besar pengelolaan hutan di Indonesia. ${ }^{10}$ Otonomi daerah memberikan wewenang bagi pemerintah daerah untuk mengelola kawasan hutan lindung, baik pemerintah daerah kabupaten/kota dan Provinsi. Kewenangan daerah dalam mengelola sektor kehutanan mencakup juga masalah pengembangan wilayah-wilayah hutan lindung sebagai sumber pendapatan daerah dengan pengembangan wisata alam.

Reformasi 1998 memberikan kewenangan besar bagi daerah untuk mengelola potensi daerah sebaik mungkin guna meningkatkan Pendapatan Asli Daerah (PAD). Hutan menjadi salah satu sektor yang mampu dikelola untuk mendapatkan pendapatan dengan berbagai metode pengembangan yang ada. Hutan lindung bisa dimanfaatkan sebagai langkah ekowisata atau dengan memberikan pengelolaan pada pihak pengembang.

\footnotetext{
${ }^{9}$ Catur Bowo Susbiarto, Penyelesaian Konflik antara Dinas Kehutanan dengan Pemegang Hak atas Tanah pada Areal yang ditetapkan Sebagai Kawasan Hutan Sekaroh, Jurnal IUS Kajian Hukum dan Keadilan, Vol. III No. 9 Edisi Desember 2015, hlm. 456-468.

${ }^{10}$ Faiqotul Falah, Kajian Implementasi Kebijakan Dalam Pengelolaan Beberapa Hutan Lindung di Kalimantan Timur, Jurnal Analisis Kebijakan Kehutanan, Vol. 4 No. 1 Edisi Maret 2007, hlm. 4-5.
} 
Lombok Timur memiliki berbagai macam destinasi wisata yang memang berbasis pada sektor kehutanan.

Pemanfaatan sektor kehutanan khususnya hutan lindung menjadi salah satu sektor yang cukup menarik bagi para investor untuk melakukan investasi dengan berbasis pada pemanfaatan jasa wisata alam. Proses alih fungsi kawasan hutan menjadi objek wisata atau kawasan wisata melalui beberapa tahapan, usulan pencadangan lokasi hutan kemasyarakat ( $\mathrm{HKm}$ ) kemudian berganti menjadi kawasan hutan dengan tujuan khusus (KHDTK). HKm pada dasarnya merupakan kawasan hutan yang dimanfaatkan oleh masyarakat berupa pemanfaatan hasil hutan dan kawasan, mengacu pada UU No. 41 Tahun 1999 HKDTK merupakan kawasan hutan yang dimanfaatkan untuk keperluan penelitian dan pengembangan pendidikan dan pelatihan serta kepentingan religi dan budaya setempat tanpa mengubah fungsi asli hutan tersebut.

Potensi wisata yang cukup besar di Kabupaten Lombok Timur dapat menarik investasi bidang pemanfaatan potensi hutan, salah satu kawasan hutan yang menarik minat investor adalah kawasan kelompok hutan Sekaroh RTK 15. Setidaknya terdapat beberapa objek wisata yang berbasis hutan yang dikembangkan oleh pihak ketiga, beberapa perusahaan yang bergerak dalam bidang pengembangan tersebut menjadikan beberapa kawasan hutan sebagai objek wisata. Terdapat tiga perusahaan asing dari enam perusahaan yang melakukan investasi di kawasan hutan Kabupaten Lombok Timur dan empat dari perusahaan tersebut beroperasi di kawasan Sekaroh RTK 15 Kecamatan Jerowaro, status perusahaan tersebut bermacam-macam, telah mengantongi izin usaha maupun dalam proses pengajuan izin. ${ }^{11}$

Status Hutan Sekaroh ialah kawasan hutan lindung yang ditetapkan pada tahun 1982, dengan Keputusan Menteri Pertanian Nomor: 759/kpts/Um/10/1982 tanggal 12 Oktober 1982 terkait Tata Guna Hutan Kesepakatan. Dengan Keputusan Menteri Kehutanan Nomor:400/Kpts-II/1990 tanggal 06 Agustus 1990 dan Keputusan Gubernur Nusa Tenggara Barat Nomor: 497 Tahun 1990 tanggal 06 November 1990 dibentuk Panitia batas Kawasan Hutan Kabupaten Lombok Timur. Sebagai rangkaian proses penetapan kawasan Sekaroh sebagai hutan lindung dengan area dan batas yang jelas.

Mengacu pada kedua keputusan tersebut, maka dilakukanlah proses pengukuran dan pemancangan batas sementara Kelompok Hutan Sekaroh dengan Register Tanah Kehutanan 15 (RTK 15) yang pada saat itu masuk pada Kecamatan Keruak. Surat perintah Kepala Balai Inventarisasi dan Perpetaan Hutan Mataram tanggal 9 Juli 1992 menjadi dasar pelaksanaan pengukuran dan pemancangan batas sementara kelompok hutan Sekaroh RTK 15 tertanggal 24 Januari 1992. Kemudian selanjutnya diikuti dengan penandatangan berita acara 14 Maret 1992. Batas hutan Sekaroh ditetapkan

${ }^{11}$ Kesatuan Pengelolaan Hutan (KPH) Rinjani Timur, Rencana Pengelolaan Hutan Jangka Panjang Tahun 20142023, Laporan, 2014, hlm. 40-43. 
secara definitif dengan proses pelaksanaan pengukuran dan pemancangan dilakukan pada tanggal 9 Juli 1994 dengan penandatangan berita acara pada tanggal 24 Maret 1994.

Pengesahan berita acara tata batas Hutan Sekaroh secara resmi disahkan tujuh tahun setelah dilakukan proses pengukuran dan pemancangan yaitu pada tanggal 02 Agustus 2002 oleh Menteri Kehutanan yang diikuti dengan penetapan Batas Kawasan Hutan Sekaroh RTK 15 Kecamatan Keruak tanggal 9 September 2002 dengan luas keseluruhan 2.834,38 Ha. ${ }^{12}$ Sejak tahun 2002 secara resmi kawasan Sekaroh menjadi kawasan Hutan Lindung yang hak pemanfaatannya dikelola oleh Pemerintah Daerah Kabupaten Lombok Timur.

\section{Permasalahan Kawasan Hutan Sekaroh}

Masalah kepemilikan dalam kawasan hutan menjadi masalah yang kerap terjadi di berbagai daerah di Indonesia. Penguasaan kawasan hutan oleh kelompok atau individu menjadi masalah yang cukup krusial, salah satunya contoh yang terjadi di kawasan hutan lindung Sekaroh. Kawasan Sekaroh seperti yang dijelaskan di atas adalah merupakan kawasan hutan lindung yang tidak mungkin dibenarkan memiliki atau menguasai tanah di areal tersebut. Namun, beberapa bagian di areal Sekaroh telah memiliki sertifikat dan dikuasai oleh beberapa oknum dan individu.

Ketidakpastian areal kawasan hutan merupakan salah satu yang menghambat efektifitas tata kelola hutan di Indonesia. Dari seluruh kawasan hutan seluas 130 juta hektar maka areal yang telah selesai ditatabatas baru sekitar 12 persen (14,2 juta hektar). Ketidakpastian ini memicu munculnya konflik tenurial (lahan) dengan berbagai pihak yang berkepentingan dengan kawasan hutan. Setidaknya 50 juta orang yang bermukim disekitar kawasan hutan dengan lebih dari 33 ribu desa yang berbatasan dengan kawasan hutan..$^{13}$

Pemerintah Kab. Lombok Timur menerbitkan Ijin Persetujuan Prinsip PT. Ocean Blue Resort No. 309/503/PPT/2015 tanggal 9 Januari 2015 seluas 136 Ha dan terjadi tumpang tindih seluas \pm 29 Ha pada wilayah ijin PT. Eco Solutions Lombok (overlaping terlampir). Masalah lahan setidaknya meliputi: terdapatnya sertifikat dalam kawasan hutan; Sporadik/Penguasaan bidang tanah; perladangan liar dan pembuatan bangunan secara liar serta penggembalaan liar. Masalah kepemilikan sertifikat menjadi masalah utama yang mengganggu proses pengelolaan hutan, setidaknya terdapat 35 nomor sertifikat yang diterbitkan oleh pihak yang berwenang. ${ }^{14}$ Masalah sertifikat ini juga

\footnotetext{
${ }^{12}$ Dinas Kehutanan Provinsi NTB, Perkembangan Kondisi Pada Kawasan Hutan Lindung Sekaroh (RTK.15) Kabupaten Lombok Timur, Arsip, hlm. 1.

${ }^{13}$ Rahmadi Rahmad, Permasalahan Tenurial dan Konflik Hutan dan Lahan, https://www.mongabay. co.id/permasalahan-tenurial-dan-konflik-hutan-dan-lahan/, diakses pada tanggal 3 Agustus 2017.

${ }_{14}$ Yon, Pembatalan Puluhan Sertifikat di Sekaroh, BPN Lotim Bersurat ke Kejaksaan, https://www. suarantb.com/pembatalan-puluhan-sertifikat-di-sekaroh-bpn-lotim-bersurat-ke-kejaksaan/, diakses tanggal 3 Agustus 2017.
} 
melibatkan beberapa pejabat terkait dengan penerbitan sertifikat di kawasan Sekaroh, pejabat Badan Pertanahan Nasional dan Kepala Desa Pemongkong. ${ }^{15}$ Proses masalah sertifikat ini ditangani oleh Kejaksaan Negeri Selong, dan terus berkembang menyeret beberapa oknum dari instansi terkait.

Terkait dengan sertifikat di hutan Sekaroh, Kepolisian Daerah Nusa Tenggara Barat berkoordinasi dengan Markas Besar Kepolisian Republik Indonesia melakukan penyelidikan khusus oleh Direktorat Reserse dan Kriminal Khusus (Ditreskrimsus). ${ }^{16}$ Berdasarkan penyelidikan ini Kejaksaan menetapkan sebanyak enam orang sebagai tersangka. Dari enam tersangka itu, lima orang merupakan mantan pejabat di Badan Pertanahan Nasional (BPN) Lombok Timur. Inisial RML mantan Kasubsi Pemberian Hak Atas Tanah BPN Lotim yang saat ini menjabat sebagai Kepala BPN Lombok Barat (Lobar). Kemudian JML, mantan Kasi Hak Atas Tanah di BPN Lotim yang kini menjabat Kepala BPN Sintang Kalimantan Barat. Selanjutnya. MM mantan Kasi Pengendalian Tanah BPN Lombok Timur dan FI mantan Kasi Pengukuran dan Penguasaan Tanah BPN Lombok Timur. Sementara satu tersangka lagi, yaitu Kepala Desa Pemongkong inisial LMM. ${ }^{17}$

Di sisi lain kasus penerbitan sertifikat di kawasan hutan Sekaroh menyebabkan kerugian negara sekitar 62 miliar. Berdasarkan hasil pemeriksaan ahli dari Kementerian Lingkungan Hidup dan Kehutanan, aset negara yang hilang itu berupa aset tanah mencapai luasan 413.903 meter persegi atau mencapai 41 hektare lebih. Kerugian negara yang nilainya mencapai 62 miliar rupiah ini tidak hanya mencakup aset tanah semata, namun keberlangsungan hidup organisme yang bergantung pada hutan lindung juga masuk dalam rincian. ${ }^{18}$ Masalah sertifikat menjadi salah satu masalah yang ada di kawasan hutan Sekaroh, selain masalah penguasaan lahan, pemukiman, pengembalaan liar dan membuka ladang secara ilegal.

\section{Kronologis Konflik Pengelolaan Kawasan Hutan Sekaroh}

PT. Eco Solutions Lombok (ESL) sebagai salah satu perusahaan yang bergerak dalam bidang pengembangan pariwisata yang berbasis pada pengelolaan sektor kehutanan. PT. Eco Solutions Lombok mengajukan permohonan IUPJLWA-PJWA ${ }^{19}$ dan IUPJLWAPSWA pada sebagian Hutan Lindung Kelompok Hutan Sekaroh, Kecamatan, Jerowaru,

${ }^{15}$ Dimas Budi Pratama, Lima Tersangka Kasus Hutan Sekaroh Jadi Tahanan Kota, https://mataram. antaranews.com/berita/33035/lima-tersangka-kasus-hutan-sekaroh-jadi-tahanan-kota, , diakses tanggal 3 Agustus 2017.

${ }_{16}$ Zainal Arifin, Gubernur NTB Minta BPN Tegas Soal Hutan Sekaroh, https://www.gatra.com/detail/news/230630-gubernur-ntb-minta-bpn-tegas-soal-hutan-sekaroh, diakses tanggal 3 Agustus 2017.

${ }_{17}$ Irwan, Kejaksaan Tetapkan 6 Tersangka Kasus Sertifikat Sekaroh, https://radarlombok.co.id/kejaksaan-tetapkan-6-tersangka-kasus-sertifikat-sekaroh.html, diakses tanggal 3 Agustus 2017.

${ }^{18}$ Miftahul Ulum, Penerbitan Sertifikat di Hutan Lindung Sekaroh Rugikan Negara Rp 62 Miliar, https://bali. bisnis.com/read/20170607/538/774055/penerbitan-sertifikat-di-hutan-lindung-sekaroh-rugikan-negara-rp62-miliar, diakses tanggal 03 Agustus 2017.

${ }^{19}$ Izin Usaha Pemanfaatan Jasa Lingkungan Wisata Alam Pada Hutan Lindung (IUPJLWA). 
Kabupaten Lombok Timur kepada Bupati Lombok Timur dengan surat Nomor: 14/ ESL/e/VII/2012, pada tanggal 12 Oktober 2012. Dalam kurun waktu enam bulan Pemda Lombok Timur memberikan respon atas proposal dan permohonan izin PT. Eco Solutions Lombok dalam pengelolaan Sekaroh.

Bupati Lombok Timur melalui Keputusan Nomor: 188.45/202/PTT/2013, tanggal 15 April 2013 memberikan izin dan persetujuan kepada PT. Eco Solutions Lombok dengan menerapkan prinsip-prinsip Pemberian Persetujuan Prinsip Usaha Pemanfaatan Jasa Lingkungan Wisata Alam Penyedian Sarana Wisata Alam Kepada PT. Eco Solutions Lombok di Tanjung Ringgit Kawasan Hutan Lindung Sekaroh (RTK.15) Kabupaten Lombok Timur. Perlu dipahami bahwa izin PT. Eco Solutions Lombok dalam pengelolaan Sekaroh dikeluarkan pada masa kepemimpinan Bupati Sukiman Azmi yaitu tahun 2013.

Dinas Kehutanan Kabupaten Lombok Timur menindaklanjuti izin yang diberikan pemerintah daerah dengan melakukan pengukuran dan menentukan daerah hutan yang akan digunakan sebagai kawasan wisata alam. Setelah melakukan pengkajian lebih dalam, maka pada tanggal 2 Agustus 2013 Tim Penataan Areal Kerja (PAK) IUPJLWAPSWA Dinas Kehutanan dan Perkebunan Kabupaten Lombok Timur menandatangani Berita Acara Hasil Tata Batas lokasi Pemanfaatan Jasa Lingkungan Wisata Alam Penyedia Sarana Wisata Alam Pada Kawasan Hutan Lindung Sekaroh (RTK.15) an. PT. Eco Solutions Lombok seluas 339 Ha. Izin PT. Eco Solutions Lombok pada level ini pada dasarnya sudah sangat kuat dan berkekuatan hukum.

Selanjutnya, Bupati Lombok Timur melalui Surat Keputusan Nomor:188.45/363/ Hutbun/2013, tanggal 26 Agustus 2013 perihal Pemberian Usaha Pemanfaatan Jasa Lingkungan Penyedia Sarana Wisata Alam Pada Blok Pemanfaatan Kawasan Hutan Lindung Sekaroh (RTK.15) Kabupaten Lombok Timur yang diberikan kepada PT. Eco Solutions Lombok seluas $339 \mathrm{Ha}$, dengan masa berlaku selama 35 tahun sejak tanggal 28 Agustus 2013 s/d tanggal 27 Agustus 2048. Dengan durasi waktu 35 tahun, hal ini menandakan bahwa izin yang dikeluarkan dan fasilitas fisik yang akan dibangun tidak permanen dan sesuai dengan peraturan-peraturan yang berlaku.

Kementerian Lingkungan Hidup dan Kehutanan melalui Direktur Perlindungan Hutan dan Konservasi Alam (PHKA) selanjutnya memperkuat dengan mengeluarkan pengesahan Rencana Pengusahaan Pariwisata Alam (RPPA) dengan Surat Keputusan Nomor; SK.227/IV-SET/2014 tertanggal 12 Agustus 2014. Dengan dikeluarkannya RPPA Kementerian Lingkungan Hidup dan Kehutanan, PT. Eco Solutions Lombok memiliki kekuatan hukum untuk melakukan pengelolaan kawasan Hutan Sekaroh sesuai dengan aturan yang berlaku.

1. Pembatalan SK Bupati Lombok Timur

Peralihan kekuasaan dalam konteks perpolitikan daerah memberikan dampak yang cukup signifikan dalam arah pembangunan. Seringkali pergantian kepala daerah 
berdampak juga pada arah kebijakan pembangunan dan kebijakan-kebijakan lain di berbagai sektor. Contoh nyata dalam hal ini adalah izin PT. Eco Solutions Lombok yang dibatalkanataudianulirolehbupatiterpilih. AliBinDahlanyangmenjadiBupatiLombok Timur menggantikan Sukiman Azmi memiliki kebijakan dan pandangan berbeda mengenai pengelolaan Hutan Sekaroh. Ali BD menganulir SK yang telah dimiliki oleh PT. Eco Solutions Lombok terkait dengan izin kelola kawasan Hutan Sekaroh seluas 339ha.BupatiLombokTimurmelaluiSuratKeputusanNomor:503/491/Hutbun/2014, tanggal 24 Oktober 2014 membatalkan izin kelola yang diberikan kepada PT. ESL. Surat keputusan ini sekaligus membatalkan dan membekukan aktivitas perusahaan tersebut di wilayah Sekaroh.

Bupati Lombok Timur Ali BD tidak hanya membatalkan izin yang dimiliki PT. Eco Solutions Lombok, namun sekaligus menerbitkan izin baru bagi beberapa perusahaan yang akan melakukan investasi di kawasan hutan Sekaroh. Izin baru ini mendapat protes keras dari pihak PT. Eco Solutions Lombok mengingat bahwa mereka telah mengantongiizinpemerintahdaerahdanpusat.Beberapaperusahaanyangmendapatkan izin, antara lain: PT. Palamarta Persada dengan Persetujuan Prinsip Nomor: 2008/ PPT/2014 pada tanggal 7 April 2014 dengan luas areal kelola 131,8 Ha; PT. Lombok Saka dengan Persetujuan Prinsip Nomor: 2007/PPT/2014 tertanggal 7 April 2014 dengan luas area 34,6 Ha; Persetujuan Prinsip IUPJLWA diberikan kepada PT. Tanah Hufa dengan Nomor: 188.45/5418/PPT/2014 tanggal 10 November 2014 luas areal 53,9 Ha. Selanjutnya, PT. Ocean Blue Resort dengan No. 309/503/PPT/2015 tertanggal 9 Januari 2015 seluas 136 Ha.

Izin yang diberikan kepada empat perusahaan di atas dapat dikatakan dengan sengaja secara cepat dibuat dan dengan proses yang tidak transparan mengajukan izin pengelolaan. MenurutSutikno selaku Kepala SeksiUsaha Kehutanan Dinas Kehutanan Provinsi NTB sekaligus sebagai tim penyidik masalah kehutanan menjelaskan bahwa Dinas Kehutanan Provinsi telah mencoba memanggil melalui surat undangan resmi seluruh pemilik perusahaan untuk dimintai keterangan sekaligus menawarkan kerjasama nyata dalam pengelolaan hutan. Namun, tidak satupun dari perusahaan tersebut yang datang menghadiri undangan dan bahkan alamat perusahaan tersebut tidak jelas serta tidak memiliki kantor resmi. ${ }^{20}$ Terdapat indikasi bahwa perusahaan ini memang dibentuk dan diberikan izin kelola dengan mudah oleh Pemerintah Kabupaten Lombok Timur dengan alasan ketidakmampuan PT. Eco Solutions Lombok secara finansial dalam membangun kawasan Hutan Sekaroh. Beberapa perusahaan tersebut juga diindikasikan kuat adalah milik Bupati Lombok Timur, namun tentunya hal ini tidak bisa dipastikan mengingat ketidakjelasan perusahaan itu sendiri.

${ }^{20}$ Wawancara dengan Sutikno, dilakukan pada tanggal 16 Juni 2017. 
Seiring dengan dibatalkannya izin yang diberikan kepada PT. Eco Solutions Lombok, pemerintah pusat melalui Kementerian Lingkungan Hidup dan Kehutanan mengeluarkan Surat Keputusan yang memperkuat posisi PT. Eco Solutions Lombok, yakniSuratKeputusanMenteriLingkunganHidupNomor:S.537/Menhut-IV/2014dan SuratDirjenPHKA Nomor:S.801/IV-PJLKKHL/2014terkaitdenganizinusahaPT.Eco SolutionsLombok.DuakeputusanMenteriyangmemperkuatPT.EcoSolutionsLombok tidak serta merta memperkuat posisi perusahaan tersebut dalam kasus pengelolaan Hutan Sekaroh. Hal ini dapat dikonfirmasi oleh kebijakan Bupati Lombok Timur yang menempatkan satuan Polisi Pamong Praja (Sat Pol PP) untuk menindak perusahaan yang tidak memiliki izin, dalam hal ini PT. Eco Solutions Lombok. Penempatan aparat keamanan sebanyak satu pleton Polisi Pamong Praja selama 24 jam di kawasan Hutan Sekaroh ini bertujuan untuk menghalau perusahaan yang tidak memiliki izin. ${ }^{21}$

2. Pemerintah Kabupaten, Provinsi dan Pemerintah Pusat

Salah satu dampak otonomi daerah adalah timbulnya masalah sinkronisasi antara pemerintah kabupaten, provinsi dan bahkan pusat. Dalam kasus Sekaroh, pemerintah telahmemberikanperingatantertulisdantegurankepadaPemerintahDaerahKabupaten Lombok Timur pasca pencabutan izin PT. Eco Solutions Lombok, antara lain: Menteri Dalam Negerimelaluisurat Nomor: 120/253/SJ/2015 tentangPenyelenggaraan Urusan Pemerintahan setelah ditetapkannya UU Nomor 23 Tahun 2014 tentang Pemerintahan Daerah; Surat Edaran Menteri Lingkungan Hidup dan Kehutanan Nomor: SE-5/ MenLHK/2015 tentang Penyelenggaraan Pemerintahan Bidang Kehutanan antara Pemerintah Pusat dan Pemerintah Daerah dan Surat Menteri Dalam Negeri Nomor: 050/1875/SJ, Hal Penyelesaian Permasalahan Proyek Kawasan Pariwisata Tanjung RinggitKabupatenLombok Timur. Ketiga perangkathukum ini menjadibagian penting dalam proses penyelesaian konflik di Hutan Sekaroh. Namun, Pemerintah Kabupaten Lombok Timur dalam hal ini terlihat enggan mematuhi dan menjalankan aturan pemerintah pusat, karena menganggap bahwa hal ini menjadi wewenang dan hak pemerintah daerah sepenuhnya.

Dalam merespon kasus Sekaroh, Gubernur NTB selaku pemangku kepentingan yang secara hierarki berada di bawah Pemerintah Pusat merespon dengan menganulir beberapa keputusan dari Bupati Lombok Timur, Ali Bin Dahlan. Gubernur NTB melalui Surat Keputusan Nomor: 522-11527 Tahun 2015, tanggal 4 September 2015 tentang Pembatalan Keputusan Bupati Lombok Timur Nomor: 2008/PPT/2014 terkait dengan Persetujuan Prinsip IUPJLWA-PSWA kepada PT. Palamarta Persada di Kawasan HutanLindung Sekaroh(RTK.15) Kabupaten Lombok Timur, Nomor:2007/PPT/2014 Persetujuan Prinsip IUPJLWA-PSWA kepada PT. Lombok Saka di Kawasan Hutan

${ }^{21}$ Lie, Pol PP Ditarik Dari Hutan Lindung Sekaroh, https://radarlombok.co.id/pol-pp-ditarik-hutan-lindung-sekaroh.html, diakses pada tanggal 03 Agustus 2017. 
LindungSekaroh(RTK.15)KabupatenLombokTimur,Nomor:188.45/5418/PPT/2014 tentang Persetujuan Prinsip IUPJLWA-PSWA kepada PT. Tanah Hufa di Kawasan Hutan Lindung Sekaroh (RTK.15) Kabupaten Lombok Timur.

Dua investor menggugat Surat Keputusan (SK) Gubernur tentang pembatalan izin investasi di kawasan Hutan Sekaroh Lombok Timur (Lotim) mencabut gugatannya di Pengadilan Tata Usaha Negara (PTUN) Mataram. Pencabutan gugatan ini dinilai karena pembatalan izin tersebut memiliki landasan hukum yang kuat. Dapat dikatakan bahwa pembatalan izin PT. Eco Solutions Lombok dan menerbitkan izin baru bagi perusahaan lain merupakan penerapan izin di atas izin. Pemerintah Provinsi NTB sering mengingatkan bupati soal pembatalan izin PT. Eco Solutions Lombok, namun tidak diindahkan. Sehingga pada akhirnya, Gubernur NTB, Dr. TGH. M. Zainul Majdi mengeluarkan SK Pembatalan Izin yang dikeluarkan oleh bupati terhadap dua investor tersebut. Pembatalan SK harus dilakukan dengan mengeluarkan SK dari lembaga yang lebih tinggi. ${ }^{22}$

Kasus Sekaroh menguras perhatian pemerintah pusat sebagai otoritas tertinggi lembaga pemerintahan, otonomi daerah yang dipahami secara berlebih menyebabkan daerahmerasamemilikikekuatan penuhdalammengeloladaerahtanpa memperhatikan kebijakan pusat dan provinsi. Bupati Lombok Timur, Ali Bin Dahlan dalam hal ini menentang keputusan Gubernur dan Menteri dalam kaitannya dengan kasus Sekaroh, dapat dilihat dari respon yang diberikan oleh Pemerintah Provinsi NTB dan pemerintah pusatdalamkonflikini.PembatalankasusinitelahdiketahuiolehPemerintahSwediayang menjadi negara asal investor PT. Eco Solutions Lombok, sehingga Pemerintah Swedia telah melayangkan protes keras kepada Pemerintah Indonesia. Melalui Menteri Dalam Negeri dan Menteri Lingkungan Hidup dan Kehutanan, Pemerintah pusat melakukan berbagai langkah dalam menyelesaikan konflik antara Pemerintah Kabupaten Lombok Timur dan PT. ESL.

\section{Upaya Penyelesaian Konflik Pemerintah Kabupaten Lombok Timur dengan PT.} Eco Solutions Lombok

Konflik merupakan fenomena yang cukup familiar dalam kehidupan sosial masyarakat, dimulai dari level akar rumput, nasional dan bahkan konflik terbuka antar negara yang menjadi isu internasional. Literatur mengenai penanganan konflik cukup banyak ditulis oleh beberapa peneliti ilmu sosial. Konflik erat kaitannya dengan kekerasan, mediasi dan intervensi. Johan Galtung memaparkan konsepsi konflik dengan sangat baik, konflik secara sederhana dapat dipahami sebagai ketidakselarasan

${ }_{22}^{2}$ Nasrullah, Bukti SK Gubernur Batalkan Izin Dua Investor Sekaroh Cukup Kuat, https://www.suarantb.com/bukti-sk-gubernur-batalkan-izin-dua-investor-sekaroh-cukup-kuat/, diakses pada tanggal 03 Agustus 2017. 
atau ketidaksamaan tujuan/kepentingan. ${ }^{23}$ Di sisi lain konflik juga erat kaitan dengan konteks, perilaku, dan sikap yang kerap dikenal dengan istilah segitiga SPK, interaksi antara ketiga komponen ini kemudian menggambarkan sebuah konflik. ${ }^{24}$ Dalam proses penyelesaian konflik, mediasi menjadi salah satu proses penting untuk memberikan wadah komunikasi yang baik antara pihak yang berkonflik. Pihak ketiga menjadi aktor penting di luar para pemangku kepentingan dalam konflik, proses mediasi merupakan proses awal membangun resolusi konflik, proses mediasi memberikan pandangan yang berbeda dari kondisi yang yang tidak menguntungkan.

Adapun alasan utama aktor dalam sebuah konflik menerima intervensi pihak ketiga atau dikenal dengan mediator antara lain adalah berangkat dari kepercayaan bahwa dengan menyerahkan penyelesaian konflik pada sebuah proses mediasi dapat menyalurkan kepentingan-kepentingan mereka dari pada membiarkan konflik tersebut tetap memanas tanpa ada proses dan regulasi yang jelas. ${ }^{25}$ Motivasi kuat lainnya mengapa pihak yang berkonflik memasukkan mediasi kedalam proses konflik antara lain. ${ }^{26}$ Pertama, mediasi biasanya menjadi sebuah pilihan kebijakan strategis ketika pihak yang berkonflik mendapat kendala dan mengadapi deadlock dalam sebuah konflik, proses mediasi ini juga dapat menjadi bagian penting pihak yang berkonflik untuk meningkatkan posisinya dalam konflik tersebut. Kedua, mediasi merupakan sebuah strategi komunikasi bersama (multiple communication strategy), strategi ini digunakan untuk meningkatkan legitimasi kebijakan-kebijakan pihak yang berkonflik. Mediasi ini juga digunakan untuk meningkatkan dukungan atau simpati di luar pihak yang berkonflik, artinya inisiatif untuk mediasi digunakan sebagai langkah politis meningkatkan dukungan, hal ini juga bertujuan untuk membuat pihak luar memberikan tekanan terhadap lawan konflik.

Upaya penyelesaian konflik antara Pemerintah Kabupaten Lombok Timur dengan PT. Eco Solutions Lombok telah melalui berbagai pendekatan dan strategi. Konflik ini juga telah mendapat respon dari Pemerintah Pusat dengan melibatkan dua kementerian terkait untuk membangun sebuah resolusi konflik. Tercatat telah dilakukan 99 kali pertemuan dengan maksud membangun sebuah resolusi konflik, baik dalam level daerah dan pusat. ${ }^{27}$ Pemerintah Kabupaten Lombok Timur dalam hal ini terbukti tidak melakukan koordinasi dan konsultasi secara benar kepada Pemerintah Provinsi NTB yang dicirikan tidak disampaikannya tembusan administratif secara hierarki. Pemerintah Kabupaten Lombok Timur juga dianggap belum tunduk dan taat terhadap

\footnotetext{
${ }^{23}$ Johan Galtung \& C. Webel, 2017, Peace and Conflict Studies, Routledge, New York, hlm. 15.

${ }^{24}$ Simon Fisher dkk, 2001, Mengelola Konflik: Keterampilan \& Strategi Untuk Bertindak, The British Council Indonesia, Jakarta, hlm. 25.

${ }^{25}$ H.J. Giesmann \& O. Wils, 2017, Seeking Compromise? Mediation Through the Eyes of Conflict Parties, Barbara Budrich Publisher, Frankfurt, hlm. 199-200.

${ }^{26}$ M. Fischer, 2011, Transitional Justice and Reconciliation: Theory and Practice, Barbara Budrich Publisher, Frankfurt, hlm. 407-410.

${ }^{27}$ Wawancara dengan Sutikno.
} 
keberadaan Undang-undang Nomor 23 Tahun 2014 tentang pemerintahan daerah serta mengabaikan surat edaran atau surat himbauan lainnya dari Pemerintah Pusat. Sebaliknya, Pemkab Lombok Timur menunjukan sikap menentang terhadap kebijakan provinsi maupun pusat yang dicirikan setiap ada kegiatan lapangan, pemerintah kabupaten selalu menempatkan Polisi Pamong Praja untuk melakukan penghadangan. ${ }^{28}$

Beberapa langkah nyata telah dilakukan untuk menyelesaikan konflik antara Pemerintah Daerah NTB dengan PT. Eco Solutions Lombok antara lain: ${ }^{29}$

1. Telah dilakukan rapat koordinasi tingkat provinsi dan pusat \pm 67 kali pertemuan;

2. Pengecekan lokasi/lapangan oleh Kementerian Lingkungan Hidup dan Kehutanan; Planologi, Gakum dan KSDAE sebanyak 6 kali;

3. Penyelidikan dan penyidikan oleh Kejari Selong bersama Dinas Kehutanan Provinsi NTB sebanyak 4 kali terhadap penerbitan sertifikat;

4. Pemanggilan dan penyidikan kepada pemilik sporadik oleh PPNS Dinas Kehutanan Provinsi NTB periode Mei 2015;

5. Pencabutan Izin Prinsip yang tumpang tindih oleh Gubernur melalui Keputusan Gubernur NTB Nomor 522.11-527 Tahun 2015, tanggal 4 September 2015;

6. Surat dari Kementerian Dalam Negeri dan Kementerian Lingkungan Hidup dan KehutanankepadaBadanPertanahanNasionalProvinsiNTBuntukmencabutsertifikat yang berada di dalam kawasan Hutan Sekaroh.

7. Pemeriksaan administratif dan lapangan oleh Tim Irjensus Kementerian Dalam Negeri sebanyak 2 kali;

8. Penempatan personil Satuan Pengamanan Hutan untuk mengamankan pekerja PT. Eco Solutions Lombok;

9. Penempatan personil SPORC (70 personil);

10. Undangan Gubernur NTB kepada para Bupati se-Provinsi NTB periode Mei 2016.

Langkah-langkah di atas adalah upaya yang dilakukan Pemerintah Pusat dan Pemerintah Provinsi untuk menyelesaikan konflik antara Pemerintah Kabupaten Lombok Timur dengan PT. Eco Solutions Lombok. Namun, Undang-undang No. 32 Tahun 2014 merupakan langkah nyata dalam menyelesaikan konflik Sekaroh. UU No. 32 tentang Pemerintah Daerah secara tidak langsung mereduksi kewenangan Pemerintah Kabupaten terkait dengan pengelolaan sektor kehutanan. UU ini dengan sangat jelas menerangkan peralihan kewenangan sektor kehutanan, perikanan dan kelautan dari pemerintah daerah kabupaten menjadi wewenang pemerintah provinsi. Sehingga perubahan kewenangan ini mendorong terbentuknya resolusi konflik antara pemerintah daerah kabupaten dan PT. Eco Solutions Lombok terkait dengan pengelolaan Hutan Sekaroh.

\footnotetext{
${ }^{28}$ Wawancara dengan Sutikno.

${ }^{29}$ Wawancara dengan Sutikno.
} 


\section{SIMPULAN}

Kawasan hutan Sekaroh ditetapkan menjadikawasan hutanlindung dengan Keputusan Menteri Pertanian Nomor: 759/kpts/Um/10/1982 tanggal 12 Oktober 1982 kemudian statusnya sebagai hutan lindung dengan hak pemanfaatannya dikelola oleh pemerintah daerah sejak tahun 2002. Kewenangan dalam pengelolaan dan pemanfaatan kawasan hutan mendorong pemerintah daerah yang berwenang mengeluarkan izin pemanfaatan untuk pihak swasta, namun muncul permasalahan karena adanya pergeseran kekuasaan dan pergantian kepala daerah. Pemerintah daerah melalui Bupati Lombok Timur, Ali Bin Dahlan, menganulir izin untuk PT. Eco Solutions Lombok (ESL) yang dikeluarkan oleh bupati sebelumnya. Upaya penyelesaian konflik ditempuh melalui proses hukum dimana konflik ini akhirnya dapat terurai seiring dengan diberlakukannya UndangUndang Nomor 32 Tahun 2014 yang menganulir kewenangan pemerintah kabupaten. Undang-Undang yang mengatur mengenai pemerintah daerah dan peralihan kewenangan pengelolaan sektor kehutanan, perikanan dan kelautan menjadi kewenangan provinsi telah memberikan dampak positif terhadap menurunnya ekskalasi konflik.

\section{DAFTAR PUSTAKA}

\section{Buku}

Fischer, M, (2011), Transitional Justice and Reconciliation: Theory and Practice, Barbara Budrich Publisher, Frankfurt.

Galtung, Johan \& C. Webel, (2017), Peace and Conflict Studies, Routledge, New York.

Giesmann, H.J \& O. Wils, (2017), Seeking Compromise? Mediation Through the Eyes of Conflict Parties, Barbara Budrich Publisher, Frankfurt.

Simon Fisher dkk, (2001), Mengelola Konflik: Keterampilan \& Strategi Untuk Bertindak, The British Council Indonesia, Jakarta.

\section{Jurnal Ilmiah}

Arifandy, M. Imam, Martua Sihaloho, (2016) Efektivitas Pengelolaan Hutan Bersama Masyarakat Sebagai Resolusi Konflik Sumber Daya Hutan, Sodality: Jurnal Sosiologi Pedesaan, Vol. 3, No. 5, Edisi Maret, hlm. 148-150.

Falah, Faiqotul, (2007), Kajian Implementasi Kebijakan Dalam Pengelolaan Beberapa Hutan Lindung di Kalimantan Timur, Jurnal Analisis Kebijakan Kehutanan, Vol. 4, No. 1, Edisi Maret, hlm. 4-5.

Laksemi, Ni Putu Sekar T., Endah Sulistyawati, Mulyaningrum, (2019), Perhutanan Sosial Berkelanjutan di Provinsi Bali (Studi Kasus di Hutan Desa Wanagiri), Jurnal Sylva Lestari, Vol. 7, No. 2, Edisi Mei, hlm. 152.

Nurkin, Baharuddin, (2006), Otonomi Daerah dan Pengelolaan Sumberdaya Alam: Kasus Pengelolaan Hutan di Sulawesi Selatan, Perennial: Pengelolaan Hutan dan Pemanfaatan Hasil Hutan, Vol. 2, No. 1, Edisi Januari, hlm. 27. 
Sumanto, Slamet Edi, (2009), Kebijakan Pengembangan Perhutanan Sosial Dalam Perspektif Resolusi Konflik, Jurnal Analisis Kebijakan Kehutanan, Vol. 6, No. 1, Edisi April, hlm. 16-18.

Susbiarto, Catur Bowo, (2015), Penyelesaian Konflik antara Dinas Kehutanan dengan Pemegang Hak atas Tanah pada Areal yang ditetapkan Sebagai Kawasan Hutan Sekaroh, Jurnal IUS Kajian Hukum dan Keadilan, Vol. III, No. 9, Edisi Desember, hlm. 456-468.

Verbist, Bruno \& Gamal Pasya, (2004), Perspektif Sejarah Status Kawasan Hutan, Konflik dan Negosiasi di Sumberjaya, Lampung Barat-Propinsi Lampung, Agrivita, Vol. 26, No. 1, Edisi Maret, hlm. 23-27.

\section{Laporan}

Dinas Kehutanan Provinsi NTB, Perkembangan Kondisi Pada Kawasan Hutan Lindung Sekaroh (RTK.15) Kabupaten Lombok Timur, Arsip.

Kesatuan Pengelolaan Hutan (KPH) Rinjani Timur, Rencana Pengelolaan Hutan Jangka Panjang Tahun 2014-2023, Laporan, 2014, hlm. 40-43.

Pidato Menteri Lingkungan Hidup dan Kehutanan Pada Apel Rimbawan Peringatan Hari Bhakti Rimbawan Tahun 2017, Kamis 16 Maret 2017.

\section{Undang-Undang}

Undang-Undang Republik Indonesia No. 32 Tahun 2014 Tentang Lingkungan Hidup dan Kehutanan.

\section{Wawancara}

Wawancara dengan Sutikno, Kepala Seksi Usaha Kehutanan, Dinas Kehutanan Provinsi Nusa Tenggara Barat.

\section{Website}

Dhimas Budi Pratama, Penyidik kejaksaan koordinasikan kasus hutan sekaroh, https:// mataram.antaranews.com/berita/38594/penyidik-kejaksaan-koordinasikankasus-hutan-sekaroh, diakses tanggal 6 Maret 2017.

Dimas Budi Pratama, Lima Tersangka Kasus Hutan Sekaroh Jadi Tahanan Kota, https:// mataram.antaranews.com/berita/33035/lima-tersangka-kasus-hutan-sekarohjadi-tahanan-kota, diakses tanggal 6 Maret 2017.

Hendra Cipto, Setiap Tahun, Hutan Indonesia Hilang 684.000 Hektar, https://regional. kompas.com/komentar/2016/08/30/15362721/setiap.tahun.hutan.indonesia. hilang.684.000.hektar. diakses tanggal 6 Maret 2017.

Irwan, Kejaksaan Tetapkan 6 Tersangka Kasus Sertifikat Sekaroh, https://radarlombok. co.id/kejaksaan-tetapkan-6-tersangka-kasus-sertifikat sekaroh.html, diakses pada tanggal 3 Agustus 2017.

Lie, Pol PP Ditarik Dari Hutan Lindung Sekaroh, https://radarlombok.co.id/pol-ppditarik-hutan-lindung-sekaroh.html, diakses tanggal 3 Agustus 2017.

Miftahul Ulum, Penerbitan Sertifikat di Hutan Lindung Sekaroh Rugikan Negara Rp 62 Milliar, https://bali.bisnis.com/read/20170607/538/774055/penerbitansertifikat-di-hutan-lindung-sekaroh-rugikan-negara-rp62-miliar, diakses 
tanggal 3 Agustus 2017.

Nasrullah, Bukti SK Gubernur Batalkan Izin Dua Investor Sekaroh Cukup Kuat, https:// www.suarantb.com/bukti-sk-gubernur-batalkan-izin-dua-investor-sekarohcukup-kuat/, diakses tanggal 3 Agustus 2017.

Rahmadi Rahmad, Permasalahan Tenurial dan Konflik Hutan dan Lahan, https://www. mongabay.co.id/permasalahan-tenurial-dan-konflik-hutan-dan-lahan/, diakses tanggal 3 Agustus 2017.

Yon, Pembatalan Puluhan Sertifikat di Sekaroh, BPN Lotim Bersurat ke Kejaksaan, https://www.suarantb.com/pembatalan-puluhan-sertifikat-di-sekaroh-bpnlotim-bersurat-ke-kejaksaan/, diakses tanggal 3 Agustus 2017.

Zainal Arifin, Gubernur NTB Minta BPN Tegas Soal Hutan Sekaroh, https://www. gatra.com/detail/news/230630-gubernur-ntb-minta-bpn-tegas-soal-hutansekaroh, diakses tanggal 3 Agustus 2017. 